\title{
An Identification On The Role Of Behavioral Finance In Invesment (A Case Study At Pandawa Cooperative)
}

\author{
Febrini Khairunnisa Imron ${ }^{1}$, Yenny Kornitasari ${ }^{2}$, Wahid Hasyim ${ }^{3}$ \\ Fakultas Ekonomi dan Bisnis, Universitas Brawijaya ${ }^{12}$, \\ OJK Departement Penyidikan Sektor Jasa Keuangan ${ }^{3}$ \\ febriniimron@gmail.com ${ }^{1}$, yenny_k@ub.ac. id ${ }^{2}$, wahid. hakim@ojk. go.id ${ }^{3}$
}

\begin{abstract}
This study discusses the role of finance in investment decision making in the Pandawa Cooperative Case Study. Offering an irrational profit of 10\% per month, the illegal investment case claimed 549 thousand victims with a total loss of Rp3.8 trillion. This research method uses a qualitative study with phenomenology to learn the truth about the role of finance in decision making which will be carried out through observations and discussions related to social phenomena related to financial roles in making investment decisions (case studies of the Pandawa Cooperative) directly in the Pandawa Cooperative case. After conducting the research process, it was concluded that the investment of the Pandawa Cooperative in investment decision making by three financial policies, namely overevidence, representative bias, and herding, which provided a role in making the Pandawa Cooperative investment decision.

Keywords: behavior finance, koperasi pandawa, investment decision.
\end{abstract}

\begin{abstract}
Abstrak
Penelitian ini bertujuan untuk mengidentifikasi peranan perilaku keuangan pada pengambilan keputusan investasi pada Studi KasusKoperasi Pandawa. Menawarakan keuntungan irasional yaitu 10 \% perbulan, KasusInvestasi ilegal tersebut ternyatatelah merenggut 549 ribu korban dengan total kerugian kerugian sebesar Rp3,8 Triliun. Metode penelitian ini menggunakan pendekatan kualitatif dengan fenomenologi untuk mengetahui kebenaran dari peranan perilaku keuangan dalam pengambilan keputusan investasi akan dilakukan melalui obseravsi maupun wawancara secara mendalam melalui fenomena sosial terkait peranan behaviour finance dalam pengambilan keputusan investasi (studi kasus Koperasi Pandawa) secara langsung dalam kasus Koperasi Pandawa. Setelah dilakukan proses penelitian, disimpulkan bahwa keputusan investasi nasabah Koperasi Pandawa dalam pengambilan keputusan investasinya dipengaruhi oleh tiga perilaku keuangan yaitu overconvidence, representative bias, dan herdingyang memberikan peranan dalam pengambilan keputusan investasi nasabah Koperasi Pandawa.
\end{abstract}

Kata Kunci: behavior finance, koperasi pandawa, keputusan investasi

\section{PENDAHULUAN}

Berdasarkan beberapa penelitian terdahulu mengenai penipuan investasi dan literasi keuangan,diketahui ternyata tingkat literasi keuangan individu secara positif mempengaruhi kemampuan untuk mendeteksi penipuan investasi (Chariri et al., 2018). Hasil survei OJK cukup menggatakan bahwa tingkat inklusi keuangan membaik dari 67,82\% pada tahun 2016 menjadi 76,19\% ditahun 2019.Terdapat ketimpangan data antara tingkat 
inklusi keuangan dan literasi keuangan.Pada tahun 2016 tingkat literasi keuangan mencapai 29,6\% dan meningkat menjadi 38,03\% ditahun 2019 (Otoritas Jasa Keuangan,2019). Dengan Index tersebut, dari setiap 100 penduduk Indonesia hanya sekitar 38,03\% atau sekitar 38 orang yang termasuk kategori well literate. Well literaredapat diartikan kemampuan personal untuk memahami dan membuat konsep keuangan yang berguna dalam hidupnya (Servon \& Kaestner, 2008). Dengan kondisi seperti ini masih banyak masyarakat Indonesia yang belum memahami dengan baik berbagai produk dan layanan jasa keuangan yang ditawarkan oleh lembaga jasa keuangan formal dan lebih tertarik pada tawaran-tawaran investasi lain yang berpotensi merugikan mereka seperti berbagai produk investasi ilegal.

Faktanya pada tahun 2007 hingga 2019 dari data Kerugian Masyarakat Akibat Kegiatan Investasi Ilegal Tahun 2007- 2019 memperlihatkan hampir setiap tahunnya selalu saja ada yang terjerumus ke dalam berbagai investasi ilegal. Jumlah dana kerugian masyarakat yang terkumpul pada tahun 2007 hingga 2019 mencapai angka Rp109,8 Triliun. Dengan total kerugian tersebut menunjukan bahwa investasi ilegal sangat merugikan masyarakat.Salah satu investasi ilegal yang banyak merenggut adalah Koperasi Pandawa. Fenomena ini dimulai dimulai sekitar tahun 2009 diawali dengan Nuryanto meminjamkan sejumlah dana kepada pedagang Usaha Kecil Menengah (UKM). Hingga akhirnya pada tahun 2015 akhirnya berkembang menjadi lembaga keuangan berizin koperasi dengan izin usaha simpan pinjam berada di wilayah Depok dengan nama Koperasi Simpan Pinjam Pandawa Mandiri Grup (KSP PMG). Pada awalnya koperasi ini melakukan kegiatan sebagaimana koperasi pada umumnya, sampai tiba koperasi ini beralih fungsi menjadi sebuah instansi yang membuat suatu badan usaha bernama Pandawa Grup. Badan usaha tersebut memberikan pinjaman yang akan dikenakan bunga sebesar 20\% (Amelia,2017).

Diawal kegiatan Koperasi ini berjalan lancar, namun di tengah perjalanan para peminjam mulai mengalami kesulitan untuk membayar hutang kepada Nuryanto, alhasil imbal hasil yang dijanjikan Nuryanto kepada para pemodal pun juga terhambat. Hingga akhirnya pada November 2016 koperasi ditutup dan dinyatakan sebagai investasi ilegal. Dari kasus tersebut ternyata merenggut 549 ribu korban dengan total kerugian sebesar Rp3,8Triliun (Otoritas Jasa Keuangan,2017). Untuk mencegah masyarakat agar tidak mudah terjerumus kedalam investasi ilegal seperti Koperasi Pandawa tersebut, maka perlu untuk mengidentifikasi perilaku keuangan yang memiliki peranan dalam pengambilan keputusan seorang investor sehingga terjerumus ke dalam berbagai investasi ilegalagar dapat dilakukan pencegahan kepada masyarakat agar kejadian serupa seperti Kasus Koperasi Pandawa tak terulang kembali.Menurut beberapa penelitian terdahulu (Nugraha,2016) mengenai investasi ilegal ditemukan bahwa investor bergabung dalam skema Ponzi di Bandung dipengaruhi oleh perilaku Herding dan overconvidence. Selain itu dalam penelitian (Jacobs \& Schain, 2011) memperoleh hasil bahwa kerentanan individu terhadap penipuan 
investasi yang berskema Ponzi disebabkan oleh informasi yang dinilai berlebihan dimana investor lebih percaya pada teman daripada informasi hasil riset sendiri. Menurut (Wilkins et al., 2012) didalam penelitian mengenai karakteristik penipuan investasi adalah lebih tua, dan berpendidikan. Dari beberapa hasil riset tersebut ternyata masih belum bisa memberikan jawaban yang memuaskan untuk menjawab bagaimanaperanan perilaku keuangan dalam pengambilan keputusan investasi khususnya membahas mengenai kasus investasi ilegal Koperasi Pandawa. Merangkum dari beberapa uraian diatas, riset ini dilakukan dengan tujuan mengidentifikasi peranan behavioural finance dalam pengambilan keputusan investasi. Penelitian ini menggunakan pendekatan kualitatif.

\section{KAJIAN LITERATUR \\ Keputusan Investasi}

Sharpe et all (2005), merumuskan investasi sebagai pengorbanan aset untuk mendapatkan keuntungan. Selain itu menurut Jones (2004) investasi sebagai komitmen menanamkan sejumlah dana pada satu atau lebih aset selama beberapa periode pada masa mendatang. Investasi dalam ekonomi islam memiliki pengertian sama dengan investasi pada umumnya namun dilandasi beberapa prinsip syariah sepertimelarang segala unsur investasi mengandung haram, gharār, maysīr, ribā, tadlīs, talaqqī al-rukbān, ghabn, darar, rishwah, maksiat and zulm karena pada umumnya investasi merupakan sebuah aktivitas muamalah yang dianjurkan dalam Islam (Pardiansyah,2017). Selain keuntungan sebagai faktor utama dalam berinvestasi, resiko menjadi pertimbangannya. Menurut (Halim, 2005) investasi selalu memiliki dua sisi, yaitu pengembalian dan risiko. Semua jenis investasi yang ada memiliki risiko baik kecil maupun besar.Investasi yang menghasilkan pengembalian investasi yang tinggi juga akan disertai dengan berbagai risiko yang tinggi. Pada dasarnya investor yang rasional akan mengerti konsep dasar investasi tersebut,seperti yang ditemukan Bailey \& Kinerson (2005) menemukan bahwa resiko merupakan predictor yang sangat kuat dalam pengambilan keputusan investasi.

Perilaku Keuangan

Menurut teori keuangan konvensional, sebagian besar orang berperilaku secara rasional dan terduga,namun ada kalanya dimana ketika emosi dan psikologi seseorang mempengaruhinya dalam mengambil keputusan yang menyebabkan individu tersebut berperilaku tidak rasional. Para ahli di bidang keuangan dan ekonomi mulai menemukan adanya penyimpangan dan perilaku yang tidak dapat dijelaskan dengan teori yang telah ada pada saat itu (M Pompian, 2006). Karena itu maka muncul teori yang dinamakan dengan teori perilaku keuangan yang akan membahas mengenai perilaku yang tidak rasional yang dipengaruhi oleh faktor psikologi yang dapat mempengaruhi seseorang dalam mengambil keputusan (Isfeni dan Novi, 2016). Selain itu, Shefrin (2000) mendefinisikan behaviour finances sebagai studi yang mempelajari bagaimana fenomena psikologi 
mempengaruhi tingkah laku keuangannya. Nofsinger (2001) mendefinisikan perilaku keuangan yaitu mempelajari bagaimana manusia secara aktual berperilaku dalam sebuah penentuan keuangan (a financial setting). Ricciardi dan Simon (2000:2) menyatakan bahwa behavioral finance secara lebih spesifik bahwa behavioral finance mencoba mencari jawaban atas what, why and how keuangan dan investasi dari sudut pandang manusia. Dalam behavioral finance juga melibatkan emosi, sifat, kesukaan dan berbagai macam hal yang ada pada diri manusia sebagai makhluk intelektual dan sosial yang akan berinteraksi melandasi munculnya keputusan dalam melakukan tindakan.Nofsinger (2001) mendefinisikan perilaku keuangan yaitu mempelajari bagaimana manusia secara aktual berperilaku dalam sebuah penentuan keuangan (a financial setting). Khususnya mempelajari bagaimana psikologi mempengaruhi keputusan keuangan, perusahaan dan pasar keuangan.Tilson (2005) menguraikan beberapa perilaku keuangan yang tidak dapat dikendalikan sehingga menyebabkan pengaruh negatif saat investor melakukan investasi.

\section{METODE PENELITIAN Pendekatan Penelitian}

Selaras dengan tujuan dari penelitian yang akan dilakukan yaitu memahami secara mendalami suatu fenomena terkait identifikasi peranan behaviour finance dalam pengambilan keputusan investasi (studi kasus Koperasi Pandawa).Studi Kasus Koperasi Pandawa merupakan suatu fenomena sosial dimana adanya keputusan investasi irasional yang 4 menyebabkan seseorang terjerumus ke dalam investasi tersebut. Koperasi Pandawa merupakan bentuk investasi ilegal yang memiliki suatu konsep investasi irasional yang merugikan nasabah dengan total kerugian hingga Rp 3,8 trilliun (Raharjo Budi,2017). Maka dalam penelitian ini akan menggunakan jenis penelitian kualitatif dengan pendekatan fenomenalogi.

\section{Unit Analisis dan Penentuan Informan}

Informan kunci adalah informan yang mengetahui secara mendalam permasalahan yang sedang diteliti. Berdasarkan tujuan pada penelitian ini yaitu untuk menganalisis keputusan nasabah investasi Koperasi Pandawa, maka Informan kunci pada penelitian ini adalah sudut pandang korban investasi ilegal yaitu mereka yang bertindak secara langsung membuat keputusan memilih Koperasi Pandawa sebagai pilihan investasi mereka saat itu.Untuk memperkuat penelitian yang diperoleh dari informan utama, peneliti juga akan menggunakan informan pendukung. Informan pendukung adalah informan yang ditentukan atas dasar pertimbangan pengetahuan yang dimiliki dan memiliki hubungan baik secara formal maupun informal dengan para informan kunci.Dalam penelitian ini ada tiga jenis sudut pandang informan pendukung yang akan dipilih yaitu dari sudut pandang Satgas Waspada Investasi, akademisi yaitu seseorang yang memiliki pemahaman lebih terkait investasi, dan Kuasa Hukum yaitu pihak yang berperan dalam proses kasus Koperasi Pandawa. 


\section{Metode Pengumpulan dan Interpretasi Data}

Metode pengumpulan yang akan digunakan adalah teknik observasi, wawancara, dan dokumentasi sebagai metode pengumpulan data. Penelitian ini menggunakan model Miles dan Huberman untuk melakukan interpretasi data. Melalui proses pengumpulan data, reduksi data, penyajian data dan penarikan kesimpulan. Uji Validitas Data Dalam penelitian ini, uji validitas data dilakukan dengan teknik triangulasi, yaitu triangulasi sumber dan triangulasi teknik.

\section{PEMBAHASAN}

\section{Overconvidence dan Keputusan investasi Koperasi Pandawa}

Dalam (Pompian M, 2006) Perilaku overconvidence dikateogrikan sebagai perilaku bias kognitif. Barber \& Odean (1999) mengartikan overconvidence sebagai perilaku percaya pada dirinya sendiri sebagai seorang idividu secara berlebihan. Menurut (Pompian M, 2006) menyebut ada beberapa gejala investor overconfidence yakni sikap terlalu yakin atas kemampuannya sendiri untuk mengidentifikasi suatu pilihan investasi yang potensial dan merasa bahwa analisis yang mereka lakukan benar dan prediksi mereka sudah tepat. Hal tersebut yang tergambar dari perilaku investasi Nasabah Koperasi Pandawa sebagai berikut:

"Pada saat itu saya merasa sangat yakin lah karena saya dapet kira-kira 2x dapet keuntungan setelah itu langsung macet." (Benny)

"Sangat yakin karena setelahnya saya dapet keuntungan setelah itu langsung macet." (Krisdianto)

Dari beberapa keterangan ternyata informan memang dilandasi kepercayaan diri yang tinggi dan beberapa kali terdapat bukti transfer keuntungan kepada para nasabah Koperasi Pandawa. Maka terdapat satu indikasi ternyata perilaku overconvidence atau perilaku terlalu percaya diri telah mempengaruhi nasabah dalam membuat keputusan berinvestasi di Koperasi Pandawa. Setelah dideteksi adanya perilaku terlalu percaya diri dalam investasi, selanjutnya menurut buku Behaivoural finance and Wealth Management (Pompian M, 2006) menjelaskan bahwa gejala investor overconfidence yang lain yaitu melakukan transaksi berlebihan karena menyangka keputusannya benar tanpa mengindahkan risiko yang ada. Hal tersebut dibenarkan oleh beberapa tindakan nasabah Koperasi Pandawa yang menginvestasikan uangnya yang tak sedikit di Koperasi Pandawa, berikut pengakuannya Bapak nasabah Koperasi Pandawa:

"Setelah membeli xenia grand ditahun 2015, dan dijual 155 juta. Terus saya masukan 85 juta sehingga 10 persennya setiap bulan saya mendapat 8,5 juta." (Krisdiharto)

"Saya hampir dua tahun kurang dan investasi hampir 200 juta, gak taunya bubar hampir stress rasanya (Sriyanti)"

"Saya jual rumah dan sekarang sudah gak punya rumah deh." (Yunita)

Berdasarkan pengalaman informan, demi berinvestasi beliau rela menjual rumah yang dimilikinya dan memasukannya ke dalam investasi 
Koperasi Pandawa. Tentu beberapa perilaku tersebut dinilai sangat berlebihan sampai tidak masuk akal. Perilaku berlebihan para nasabah dalam berinvestasi di Koperasi Pandawa didukung oleh laporan CNN bahwa korban penipuan dan penggelapan investasi bodong Pandawa Group mencapai ratusan ribu orang. Kerugian korban diperkirakan mencapai Rp3 triliun (Amelia Mei, 2017). Dari penuturan beberapa informan terbukti bahwa para nasabah dalam berinvestasi di Koperasi Pandawa terlampau berlebihan tak mengheran bila perilaku overconvidence menjadi salah satu perilaku yang memberikan peranan pada pengambilan keputusan investasi Koperasi Pandawa seperti halnya penelitian yang dilakukan (Umairoh,2012) variabel overconfidence terbukti berpengaruh signifikan terhadap keputusan investasi.

\section{Representative Bias dan Keputusan Investasi}

Koperasi Pandawa Representativeness bias adalah perilaku ketergantungan pada stereotip, analogi, atau sampel terbatas untuk membentuk opini secara keseluruhan atas sebuah kelompok (Ross, et al., 2016). Menurut (M. Pompian,2006) perilaku representative bias termasuk ke dalam perilaku bias kognitif yang artinya, representativeness bias adalah proses ketergantungan berlebihan pada stereotip. Menurut Kahneman dan Tversky (1979) Representativeness adalah heuristik kognitif yang ditandai oleh kecenderungan individu dalam mempertimbangkan pengambilan keputusan berdasarkan pada karakteristik yang menjadi wakil dari seluruh fenomena. Dapat ditarik kesimpulan bahwa perilaku Representative Bias adalah perilaku bias dalam membentuk sebuah opini pada sampel yang terbatas, dan menjadikan suatu keputusan individu berdasarkan karaktersitik umum yang menjadi wakil dari seluruh fenomena. Menurut (Pompian M, 2006) dalam bukunya Behavioural Finance and Wealth Management untuk mengidentifikasi gejala representative bias pada investor kita dapat melihat dari perilaku bias investor ketergantungan kepada stereotip yang berlebihan atau biasa disebut Base-Rate Neglect.Ketika suatu kelompok dengan suatu stereotip baik yang melekat padanya, maka masyarakat akan cenderung memandang apapun yang dilakukan kelompok tersebut baik. Stereotip merupakan jalan pintas dalam berfikir. Menurut kajian yang dilakukan oleh (Marzali Amri, 2016) agama dapat menentukan mana tingkah laku yang salah dan mana yang benar. Yang salah akan dihukum, masuk neraka, dan yang benar akan diberi anugerah, masuk surga. Menurut Kamus Besar Bahasa Indonesia (KBBI) agama adalah suatu keyakinan atau kepercayaan yang dianut seseorang yang dipercaya dapat mengarahkan seseorang untuk menjalani hidup yang lebih baik. Artinya disini agama adalah hal baik atau petunjuk yang dapat menuntut seseorang menjadi lebih baik. Maka tak mengherankan investasi dengan label agama tertentu akan cenderung mudah menggiring opini masyarakat untuk berfikir bahwa investasi tersebut baik, padahal pemikiran tersebut bias dan terlalu berlebihan dalam memandang stereotip. Kecenderung seperti ini nampaknya 
terlihat pada perilaku nasabah Koperasi Pandawa dalam memutuskan bergabung berinvestasi, berikut pengakuan Bapak Hendry Bondan nasabah Koperasi Pandawa:

"Saya tergiur bunga besar dengan ajakan teman saya yakin tidak akan terjadi apa-apa karena ada kalangan ustad yang ikut serta dalam koperasi tersebut" Berdasarkan pengalam informan diatas alasan nasabah tergiur dengan investasi KSP Pandawa adalah karena bunga besar yang ditawarkan, selain itu keyakinan untuk menjadi percaya akan investasi KSP Pandawa adalah karena ada kalangan ustad atau tokoh agama di dalamnya. Istilah agama tersebut dibawa agar psikologis calon nasabah menjadi 6 yakin praktik pengelolaan dana investasi yang dilakukan seolah-olah syariah. Hal tersebut juga yang dirasakan oleh Bapak Iyus Alcan salah satu nasabah Koperasi Pandawa, berikut pengakuannya:

"Awal tertarik karena testimoni dari ustad dan tokoh masyarakat, dengan berkedok arisan dan silaturahmi"

Berdasarkan keterangan dari informan, beliau mengakui bahwa dalam proses penawaran investasi Koperasi Pandawa memberikan unsurunsur agama di dalamnya seperti testimony dari para ustad, atau mengadakan pengajian-pengajian sehingga informan merasa tertarik untuk ikut berinvestasi di Koperasi Pandawa. Tak hanya beberapa nasabah yang merasakan adanya pembawaan agama di dalam unsur bisnis Koperasi Pandawa, tetapi saksi atas kasus Koperasi Pandawa yaitu Bapak Wahid dari Satgas Waspada Investasi juga mengakui adanya unsure agama di dalam penghimpunan dana koperasi tersebut, berikut pengakuannya:

"Karena dengan pakaian pa nuryanto yang memakai jubah putih dan sering mengadakan pengajian seolah-olah kegiatan yang dilakukannya syariah ternyata kegiatan konvesional sehingga kegiatannya ribawi. “ Berdasarkan pemaparan Bapak Wahid, pada saat itu pendiri Nuryanto sebagai Koperasi Pandawa ataupun Pandawa Mandiri Grup menggunakan unsur-unsur syariah seperti penggunakan pakaian jubah putih,ataupun mengadakan pengajian agar seolah-olah kegiatan yang dilakukannya dekat dengan agama."

Dari pemaparan beberapa informan diatas dapat disimpulkan bahwa nasabah Koperasi Pandawa Mandiri Grup telah terindikasi dipengaruhi oleh Base Rate Neglect atau setreotip agama untuk memberikan kesan investasi yang baik. Hal tersebut didukung oleh adanya pencatutan nama sejumlah tokoh pemuka agama Islam dalam hal ini ustaz dan atau sebutan lain dalam berbagai propaganda dan pemasaran produk jasa KSP Pandawa Mandiri Group (Kandi Dewi,2017). Indonesia sebagai negara dengan penduduk beragama islam terbanyak didunia, tentu banyak yang berpandangan untuk menjadi pemeluk agama yang taat dengan melakukan segala aktivitasnya dekat dengan unsur-unsur syariah. Namun sayangnya masih banyak masyarakat yang memandang unsurunsur agama hanya tampak dipermukaannya. Hal tersebut yang diungkapkan oleh Bapak Anas selaku akademisi Universitas Brawijaya, berikut penyampaiannya: 
"Berapa banyak masyarakat kita yang tertarik karena apa yang terlihat." Berdasarkan pernyataan tersebut beliau menyetujui bahwa masyarakat kita saat ini banyak yang mudah percaya dengan apa yang terlihat atau "what beyond the display", dengan penampilan yang tampak agamis adalah baik sehingga masyarakat lebih mudah tertarik dan percaya. Sehingga tak mengherankan bila Koperasi Simpan Pinjam Pandawa, Pandawa Mandiri Grup ataupun Nuryanto menjadikan unsur-unsur syariah menjadi metode pemasaran untuk membangun citra baik dan jauh dari penipuan. Seperti yang dikatakan MUI Depok, dimana Koperasi Pandawa melakukan Penggiringan opini bahwa seolah-olah Pandawa menganut sistem syariah (Kandi Dewi,2017). Selain berlebihan memandang stereotip pada suatu kelompok tertentu. Menurut (Pompian M, 2006) untuk mengidentifikasi gejala representative bias pada investor kita dapat melihat dari perilaku bias investor dalam memandang sampel yang terbatas atau biasa disebut SampleSize Neglect. Seperti halnya dikatakan oleh (Kim dan Byun, 2011) bahwa kecenderungan investor untuk memulai penilaian investasi tertentu melalui pengamatan terhadap sampel data yang tidak memadai untuk dianalisis.Nampaknya perilaku tersebut tampak pada perilaku investasi nasabah Koperasi Pandawa, karena hanya dengan beberapa contoh studi kasus beberapa nasabah, Bapak Krisdiharto tampak percaya kasus tersebut dapat mewakili seluruh fenomena yang ada, berikut pengakuannya:

"Banyak ada Pa RT dan tetangganya, bahkan banyak dari orang-orang didaerah rumah pa RT yang ikut karena saat itu acara tujuh belasan ditahun 2017 penutupan acara tujuh belasan“ Berdasarkan pengalaman informan, beliau merasa semakin yakin untuk berinvestasi dikoperasi pandawa setelah melihat satu tetangganya, dan ketua RTnya tampak sukses meningkatkan taraf 7 keuangannya dengan mengikuti Koperasi Pandawa hingga bisa membiayai acara tujuh belas agustus warga. Selain itu kecenderungan tersebut terlihat didalam para nasabah yang mengambil keputusan investasi dengan melihat wakil dari populasi nasabah yang berhasil menjadi sukses dengan berinvestasi di Koperasi Pandawa, berikut penjelasannya :

"Leader saya menceritakan beberapa cerita sukses ikut koperasi pandawa, tukang parkir awalnya nanam 5 juta lama-lama bisa kebeli motor dan benahi rumahnya dan lain sebagainya. Dia sendiri awalnya mobil HRV dijual membeli BRV. percaya salah satunya karena diacara 17an ketua RT itu yang sponosrin jadi makin percaya (krisdianto). "Percaya karena leader orang orang beacukai dan dia bilang sendiri kalau saya tidak memamerkan kepunyaan saya tidak aka nada yang tertarik jadi saya memperlihatkan contoh pake pajero (Benny)"

Berdasarkan pernyataan informan mengakui dengan cerita sukses beberapa nasabah semakin yakin untuk masuk kedalam investasi Koperasi Pandawa. Dari beberapa pengalaman informan diatas dapat disimpulkan terdapat gejala Sample Size Neglect yaitu bias memandang populasi pada pengambilan keputusan investasi nasabah Koperasi Pandawa secara tidak langsung tertarik untuk berinvestasi di Koperasi Pandawa karena adanya 
cerita sukses dari hanya beberapa orang yang sebenarnya tidak dapat mewakili rata-rata cerita nasabah lainnya. Pengelola skema umumnya membingkai informasi dengan frame positif, yaitu memberikan informasi yang baik kepada calon investor, misalnya keberhasilan orang yang sudah dapat keuntungan. Hal ini sesuai dengan penelitian sebelumnya yang dilakukan (Nugraha, 2016) melihat ternyata representative bias memberikan pengaruh positif kepada investor dalam memilih investasi dalam skema Ponzi dan piramida. Meskipun beberapa bukti tersebut dapat meyakinkan bahwa koperasi pandawa adalah investasi yang bagus dan dapat dipercaya, nyatanya sekarang KSP Pandawa Mandiri Grup tercatat sebagai investasi ilegal yang merugikan ratusan ribu nasabah sehingga gejala perilaku representative bias memberikan pengaruh negative pada nasabah.

\section{Herding dan Keputusan Investasi Koperasi Pandawa}

Perilaku Herding adalah perilaku menggiring yang juga merupakan bentuk bias kognitif yang dilakukan olehinvestor dan mendasarkan keputusan investasi mereka dan bukan berdasarkan pertimbangan dasar fundamental ekonomi dari aset yang berisiko ,tetapi dengan melihat tindakan investor lain yang dianggap memiliki informasi lebih (Nugraha, 2016). Menurut (Virigineni \& Bhaskara, 2017) Investor yang tergolong kedalam perilaku Herding memiliki maksud yang jelas untuk mengabaikan informasi pribadi mereka dan meniru perilaku investor lain.Sehingga gejala investor yang dengan perilaku tersebut ditandai dengan keputusan berinvestasi yang dipengaruhi oleh investor lain dan bukan atas keputusannya sendiri. Perilaku tersebut nampaknya terlihat pada perilaku berinvestasi nasabah Koperasi Pandawa keputusan nasabah KSP Pandawa Mandiri Grup banyak dipengaruhi oleh orangorang yang ada disekitarnya. Perilaku tersebut di dalam teori perilaku keuangan dikategorikan sebagai perilaku Herding atau perilaku ikut-ikutan. Menurut pengakuan Bu Sriyanti Ekaputri, informan yang menjadi nasabah di Koperasi Pandawa, awal tertarik untuk ikut Koperasi Pandawa dikarenakan ajakan dari salah satu anggota keluarganya, "Sebetulnya saya ikut karena ponakan ikut dan sifatnya hanya menawarkan kepada saya." (Sriyanti) "Saya awal ikut pandawa karena diajak sama temen suami saya yang sudah gabung satu tahun." (Ibu Yunita Yati) "Temen karena dia dari beacukai, kan saya dari pabrik rokok dan murni karena teman." (Bapak Benny).

Beberapa pengalaman dari para nasabah membuktikan bahwa orangorang terdekat seperti keluarga maupun teman secara psikologis dapat mempengaruhi perilaku keuangan individu dalam membuat keputusan investasi. Keluarga ataupun kerabat merupakan kelompok masyarakat yang pada umumnya memiliki tingkat kepercayaan dan emosional yang lebih dibanding ikatan sosial 8 lainnya sehingga keputusan investasi yang mereka lakukan sebenarnya adalah atas dasar percaya kepada anggota keluarga atau kerabat yang menawarkan produk investasi bukan atas dasar informasi seutuhnya tentang investasi yang ditawarkan. Hal tersebut didukung oleh penelitian yang dilakukan oleh (Nugraha, 2016) dimana perilaku Herding 
termasuk memiliki pengaruh yang tinggi dalam membuat keputusan investasi dengan skema Ponzi. Selain itu penelitian yang dilakukan (Jacob\& Schain,2011) ternyata Perencana Ponzi bergantung pada fakta bahwa investor yang sering mengikuti kenalan dengan teman dalam berinvestasi dan tertarik pada skema Ponzi. Dapat disimpulkan bahwa dari beberapa indikasi diatas dapat diindentifikasi bahwa perilaku Herding merupakan salah satu perilaku behaviour finance yang memberikan peranan dalam pengambilan keputusan investasi pada nasabah Koperasi Pandawa. Hal tersebut diwakili oleh perilaku nasabah yang tertarik pada Koperasi Pandawa karena ikutikutan teman atau keluarga ketika mempertimbangkan keputusan investasi tersebut. Hal tersebut sesuai dengan pernyataan informan Pak Anas, yaitu informan yang berperan sebagai Akademisi di Universitas bahwa ada beberapa penyebab investasi ilegal berskema Ponzi menggunakan perilaku Herding untuk menarik nasabah untuk berinvestasi yang diantaranya adalah:

"Sistem seperti ini kan mungkin ditawarkan sekali enggak, dua kali masih mikir, ketiga kali oke boleh dicoba. Maka perlu pendekatan yang terus menerus sehingga dia membutuhkan pendekatan yang lebih sering dan mudah ya makanya menggunakan pendekatan seperti keluarga karena lebih mudah karena memiliki kedekatan emosinal."

Berdasarkan pernyataan informan, dengan menggunakan pendekatan perilaku khususnya Herding, seorang individu yang awalnya ragu setelah sekali dua kali dan seterusnya diberikan pendekatan baik secara emosional sebagai orang-orang terdekat seperti keluarga, ataupun teman pada akhirnya individu tersebut menjadi percaya secara sadar ikut menjadi nasabah sehingga untuk menghindari keputusan investasi yang keliru akibat perilaku ikut-ikutan sebelum berinvestasi harus memahami secara detail dan terperinci investasi apa yang ditawarkan tersebut.

\section{Behaviour Finance dan Keputusan Investasi Nasabah}

Dalam membuat suatu keputusan berinvestasi, seorang investor bisa dipengaruhi oleh perilaku pasar dan perilaku investor itu sendiri baik secara rasional maupun irasional. Karena saat ini dalam melakukan kegiatan investasi, investor tidak hanya menggunakan estimasi atas prospek instrumen investasi saja tetapi juga sudah memasukkan faktor psikologi. Bahkan banyak pihak yang sudah menyatakan bahwa faktor psikologi investor memiliki peran yang paling besar dalam menentukan investor untuk berinvestasi (Isfeni dan Novi, 2016). Seperti halnya dalam penelitian (Dwi,2016) yang menunjukan bahwa ternyata perilaku keuangan baik rasional maupun irasional sudah mendapatkan tempat bagi investor dalam mengambil keputusan berinvestasi. Menurut (Lewis, M. K. 2012) dalam penelitiannya bahwa psikologi memiliki banyak kontribusi untuk memahami mengapa orang menjadi korban skema Ponzi. Tapi manusia tidak selalu rasional karena ada pengaruh psikologis yang diwujudkan dalam bias perilaku. Faktor psikologis itu mempengaruhi seseorang untuk berinvestasi dalam skema Ponzi dan piramida (Elan, 2010; Lewis, 2012). Pengaruh negatif 
yang diberikan faktor psikologis atau perilaku keuangan diantara lain disebabkan konsep rasional investor yang memiliki penyimpangan bias secara social, kognitif, dan emosi (Widyastuti) Berdasarkan pengalaman beberapa nasabah Koperasi Pandawa, ditemukan ternyata ada beberapa gejala perilaku keuangan yang dipengaruhi oleh beberapa bias cognitive yang diantaranya adalah peranan perilaku percaya diri berlebihan (overconvidence), perilaku menggiring (Herding) dan bias keterwakilan (representative bias) dalam keputusan investasi nasabah Koperasi Pandawa. Studi terdahulu tentang perilaku keuangan membenarkan jika psikologi kognitif untuk memainkan peran penting yang potensial 9 dalam keuangan. Pendekatan ini menawarkan penjelasan yang lebih baik tentang faktorfaktor yang relevan yang mempengaruhi skema Ponzi keputusan investasi (Nugraha, 2016).

Menurut (Pompian M, 2016) akibat dari adanya perilaku keuangan yang dikategorikan sebagai bias cognitive akan memunculkan penilaian investasi yang tidak rasional. Karena bias kognitif berasal dari penalaran yang salah adalah akibat dari kurangnya pengetahuan dan kemampuan individu dalam memahami keuangan. Kurangnya pengetahuan masyarakat ternyata didukung oleh fakta data daritingkat pengetahuan keuangan masyarakat Indonesiapada tahun 2019 sebesar 38,03\%. Dengan Index tersebut, dari setiap 100 penduduk Indonesia hanya sekitar 38,03\% atau sekitar 38 orang yang termasuk kategori well literate ataudapat diartikan sebagai kemampuan personal untuk dapat memahami mengenai konsep dan pengetahuan keuangan (Servon and Kaestner, 2008). Dengan tingat literasi keuangan masyarakat Indonesia yang rendah tak mengeherankan bila bias cognitive yang ada dalam perilaku keuangan seperti overconvidence, representative bias, dan Herding dapat memberikan peranan dalam pengambilan keputusan investasi nasabah Kasus Koperasi Pandawa. Sehingga menurut pakar psikologi keuangan cara untuk menghindari dan mencegah bias cognitive adalah dengan meningkatkan kemampuan dan pengetahuan seorang individu dalam berpikir secara rasional untuk meghasilkan keputusan yang tepat (Pompian M,2016). Artinya disini untuk mencegah bias cognitive individu untuk memainkan peranan yang terlalu berlebihan dalam membuat suatu keputusan investasi, perlu adanya peningkatan pengetahuan dan pemahaman tentang produk-produk investasi tersebut.

Dalam penelitian yang dilakukan oleh (Lokanan, 2014) ternyata literasi keuangan atau pengetahuan keuangan merupakan elemen penting dari aktivitas investasi, sehingga dengan literasi keuangan yang baik seseorang dapat menghindari penipuan investasi. Sebagai seorang Akademisi Universitas Brawijaya, Wahid memandang literasi keuangan masyarakat yang rendah merupakan salah satu penyebab kasus penipuan investasi seperti yang dilakukan Koperasi Pandawa pada tahun 2016 terjadi. "Karena jaman sekarang susah sih, belum tentu orang yang berpendidikan tinggi tidak tertarik, maka orang yang tidak tertarik itu orang yang memiliki literasi 
keuangan yang tinggi jadi belum tentu orang yang berpendidikan punya literasi keuangan yang tinggi."

Berdasarkan pemaparan tersebut informan berpendapat bahwa belum tentu orang berpendidikan tidak tertarik dengan tawaran investasi irasional yang ditawarkan Koperasi Pandawa, justru orang-orang yang tidak tertarik adalah mereka yang memiliki tingkat literasi keuangan yang tinggi. Hal tersebut sejalan dengan penelitian yang dilakukan (Chairi Anis,2013) yang menemukan bahwa tingkat pendidikan seseorang tidak mempengaruhi kemampuannya dalam mendeteksi penipuan investasi. Hal ini didukung oleh kesimpulan penelitian yang dilakukan oleh Lewis, M. K. (2012) yang menunjukkan kurangnya melek finansial dasar menyebabkan para pembuat keputusan untuk tidak kritis dan mengabaikan bukti dan tanda-tanda peringatan yang akan menantang keyakinan mereka. Selain itu pentingnya literasi keuangan dijelaskan oleh Bapak Wahid sebagai Satgas Waspada Investasi, berikut pernyataannya:

"Untuk mencegah yang kita lakukan ada pengurangan, yaitu edukasi dan sosialisasi pengetahuan keuangan kepada masyarakat."

Berdasarkan informan, menurutnya penipuan investasi seperti Koperasi Pandawa akan selalu ada sepanjang permintaan dan pemahaman akan keuangan masyarakat masih kurang sehingga dengan edukasi dan sosialisasi keuangan kepada masyarakat menjadi penting untuk melakukan pencegahan terkait penipuan investasi. Penelitian yang dilakukan oleh Lusardi (2012) ditunjukan bahwa memang ternyata kemampuan masyarakat untuk membuat keputusan keuangan akan meningkatkan kemampuan pengolaan peribadi mereka. Selain adanya pandangan secara umum tentang pentingnya literasi keuangan dalam pengambilan keputusan investasi. Di 10 dalam Ekonomi Islam juga mendukung adanya peningkatan pengetahuan dan pemahaman mengenai produk investasi sebelum seorang investor terjun ke dalamnya. Hal tersebut kurang lebih yang dijelaskan oleh Bapak Anas Akademisi Universitas Brawijaya mengenai pentingnya pengetahuan keuangan di dalam ekonomi islam: "Pertama menurut saya literasi keuangan itu pondasinya harus islam dulu dalam hal ini fiqih muamalah."

Berdasarkan pernyataan informan tersebut, Ekonomi Islam memandang seseorang dalam berinvestasi seharusnya sudah mengerti fiqih muamalah atau bagaimana Islam memandang investasi tersebut sehingga investor tidak mudah terjerumus kedalam penipuan-penipuan investasi. (Pardiansyah Elif, 2017) menguraikan hubungan investasi dan Islam, dasar prinsip syariah dalam berinvestasi, asas fiqih muamalah, yang digunakan dalam kegiatan investasi agar semua pihak yang berkepentingan dalam kegiatan ini dapat membedakan dan memilih investasi mana yang boleh, halal, dan baik. Hal tersebut juga ditegaskan oleh (Putra Wardy,2018) dengan maraknya investasi "bodong" atau penipuan investasi yang semakin marak dari waktu ke waktu sehingga penting untuk memahamkan kepada masyarakat terkait investasi yang sesuai dengan Ekonomi Islam berdasarkan panduan Al-Qur'an dan Hadits. Dengan harapan masyarakat akan lebih 
mengetahui terkait jenis-jenis investasi yang dibolehkan dan yang dilarang dalam syariah.

\section{SIMPULAN}

Penelitian ini menemukan adanya perilaku keuangan yaitu overconvidence, representative bias, dan Herding yang memberikan peranan dalam pengambilan keputusan investasi nasabah Koperasi Pandawa. Dengan adanya beberapa perilaku keuangan tersebut dapat disimpulkan bahwa perilaku cognitive bias muncul akibat kurangnya informasi dan pengetahuan calon nasabah untuk memutuskan suatu keputusan investasi, akibatnya calon nasabah menjadi bias dalam memilih investasi. Keputusan yang bias tersebut akan menggiring seorang individu untuk membuat keputusan keuangan yang keliru seperti menjerumuskan ke dalamberbagai sektor jasa keuangan ilegal seperti kasus Koperasi Simpan Pinjam Pandawa Mandiri Grup. Adanya perilaku keuangan yang dikategorikan sebagai bias cognitive akan memunculkan penilaian investasi yang tidak rasional. Bias cognitiveberasal dari penalaran yang salah adalah akibat kurangnya pengetahuan dan kemampuan individu dalam memahami keuangan. Berdasarkan Index Literasi Keuangan Indonesia Tahun 2019, dari setiap 100 hanya sekitar 38 orang atau sekitar 38\% penduduk Indonesia yang dapat kategorikan well literate danpaham mengenai membuat konsep dan pengetahuan keuangan. Dengan tingat literasi keuangan masyarakat Indonesia yang rendah tak mengeherankan bila bias cognitive yang ada dalam perilaku keuangan seperti overconvidence, representative bias, dan herding dapat memberikan peranan dalam pengambilan keputusan investasi nasabah Kasus Koperasi Pandawa. Sehingga menurut pakar psikologi keuangan cara untuk menghindari dan mencegah bias cognitive adalah dengan meningkatan kemampuan, dan pengetahuan seorang individu dalam berfikir secara rasional untuk meghasilkan keputusan yang tepat. 


\section{DAFTAR PUSTAKA}

Amelia, Mei. (2017).Begini Modus Nuryanto dalam Penipuan Investasi PandawaGroup.Detik.com.Retrievedfrom https://news.detik.com/berita/d-3428257/begini-modus-nuryantodalam-penipuan-investasi-pandawa-group.

Bailey, Jeffrey J \& Chris Kinerson, 2005. "Regret Avoidance and Risk Tolerance". Association for Financial Counseling and Planning Education, pp. 23-28.

Chariri, A. Nurlina W, Wulandari R. W. (2018). Individual Characteristics, Financial Literacy and Ability in Detecting Invesment Scam. Jurnal Akuntansi dan Auditing . 15(1).91-114.

Isfeni dan Novi,(2016). Perilaku Keuangan: Teori dan Implementasi. Medan :Pustaka Bangsa press.

Jacobs, P., \& Schain, L.(2011). The Never Ending Attraction of the PonziScheme. Journal of Comprehensive Research. 9.40-46.

Jones, Charles P Jones. (2004), "Investments: Analysis and Management", Sixth edition, Willey.

Lewis, M. K. (2012). New Dogs, Old Tricks. Why Do Ponzi Schemes Succeed?. Accounting Forum, 36(4), 294-309.

Lokanan, M. E., 2014, The Demographic Profile of Victims of Investment Fraud Canadian Perspective, Journal of Financial Crime, Vol. 21, No. 2, 226-242.

Lusardi, A., \& Mitchell, O. (2007). Financial Literacy and Retirement Preparedness: Evidence and Implications for Financial Education. Business Economics. 42(1).

Nofsinger, J., R. (2001). Investment Madness: How psychology affects your investing and what to do about it, Prentice Hall.

Nugraha, Sari. (2016). Cognitive Bias and Risk Preferences Analysis of PonziScheme Investors. Vol (15). In 1st Global Conference on Business, Management and Entreupreuneurship (GCBME- 16). Advances in Economics, Business and Management Research.

OJK. 2019a. Siaran Pers OJK: Indeks Literasi Dan Inklusi Keuangan Meningkat. Available at: https://www.ojk.go.id/id/beritadankegiatan/siaran- pers/Pages/SiaranPers-OJK-Indeks-LiterasidanInklusi-Keuangan-Meningkat.aspx (Accessed: 23 Desember 2019).

OJK. 2019a. Laporan Satgas Waspada Investasi 2018 (Accessed: 23 November 2019).

Pompian, M. M.(2006). Behavioral Finance and Wealth Management: How to Build Investment Strategies That Account for Investor Biases. Wiley Finance.

Putra, Wardy. (2018). Investasi Dalam Ekonomi Islam. Jurnal Ulumul Syar'i. $7(2)$.

Wilkins, Acuff,\& Hermanson. (2012). Understanding a Ponzi Scheme: Victims' Perspectives. Journal of Forensic \& Investigative Accounting, 4(1). 
Ricciardi V. And Simon, H, K. (2000). What is Behavior in Finance? Business, Education,and Technology Journal,2. (1-9).

Tilson, Whitney. (2013). Applying Behvioral Finance to Value Investing. Artikel T2. Partner LLC. http: zllwww.T2 PartenrsLLC.com. Diakses tanggal 21 Januari 2020

Pardiansyah, Elif. (2017). Investasi dalam Perspektif Ekonomi Islam: Pendekatan Teoritis dan Empiris. Economica: Jurnal Ekonomi Islam.8(2).

Umairoh, Pradiptaning. 2013. Cognitive Bias dan Emotional Bias Dalam Pengambilan Keputusan Investasi Portofolio. Jurnal online Universitas Kristen Satya Wacana

Rokhman, W. (2013). The Effect of Islamic Microfinance on Poverty Alleviation: Study In Indonesia. Economic Review: Journal of Economics and BusinessVol 11(2). 21-30.

Rokhman, W. (2016). Islamic Management Practices in Islamic Microfinance: an Empirical Study. Yogyakarta: Idea Press.

Sharpe, William F., Gordon J. Alexander, \& Jeff ery V. Bailey, (2005). Investasi Edisi Keenam, Jilid I, Edisi Bahasa Indonesia, PT. Indeks Kelompok Gramedia, Jakarta. 
Febrini Khairunnisa Imron, Yenny Kornitasari \& Wahid Hasyim

Halaman ini sengaja dikosongkan 